\title{
Religious Moderation in Pre-Marriage Courses
}

\author{
Daniel Rabitha, Ismail ${ }^{1}$, dan Novi Dwi Nugroho ${ }^{2}$ \\ \{mrabitha@gmail.com ${ }^{1}$, ismail.zubir@gmail.com², novdwinu@gmail.com ${ }^{3}$ \}
}

Balai Litbang Agama Jakarta, Jl. Rawa Kuning No. 6 Pulogebang, Cakung, Jakarta Timur

\begin{abstract}
The research was conducted at several Subdistrict Religious Affairs Office (KUA) in Purwakarta Regency, Indramayu Regency, and Banjar City, West Java Province. This research was conducted on the prospective bride and groom participants at the pre-marriage course held by Subdistrict Religious Affairs Office (KUA) in prior to April 2015. This research understands the possibility of fostering a moderate attitude in preparing household relationships. Research using the concept of change management by Kurt Lewin consists of 3 stages of the model, namely Unfreezing, Moving, and Refreezing. This study provides an understanding that the cultivation of moderate attitudes is a major part of changing old habits to new habits, and this can occur during pre-marital courses.
\end{abstract}

Keywords: Pre-Marriage Course, Moderate Attitude, Three Stages of Change, Kurt Lewin.

\section{Preliminary}

Currently, the Indonesian people are facing the industrial revolution 4.0. Efforts are made to continue state policy to respond to these conditions. For example, the Ministry of National Development Planning (Bappenas) made the concept of quality and competitive Indonesian human development with the principles of being healthy, smart, adaptive, creative, innovative, skilled, and dignified (Director of Education and Religion, Ministry of National Development Planning/Bappenas, Role of Research on Religious Harmony for Development Planning National, 2019). One of the priority programs to support human development in Indonesia is to achieve family resilience. In addition, Indonesia is known to have a fairly dense population in the world. The fourth position of the population in the world, making Indonesia has considerable human capital, but it could also become an obstacle due to the population explosion. So that the government and society realize that realizing and striving for the population of the Indonesian people to become a big capital with the resilience of family resilience.

The Ministry of Religion, through the Pre-Marriage Course or previously known as "Suscatin (Bridal Candidate Course"), seeks to build family resilience through the prospective bride and groom. Regulatory regulations have been issued by the Ministry of Religion to improve the implementation of the Pre-Marriage Course. For example, Perdirjen Bimas Islam Number DJ.II / 491/2009 concerning Bride Candidates Course, Perdirjen Bimas Islam Number DJ.II / 372/2011 concerning Guidelines for Implementing Pre-Marriage Courses, and 
Perdirjen Bimas Islam Number DJ.II / 542/2013 concerning Guidelines Pre-Marriage Courses. All of these regulations are related to the family principle expected by the state and the Indonesian people.

One of the Work Units commonly known by the Muslim community as a place for marriage permits and pre-marriage courses is the Subdistrict Religious Affairs Office (KUA) (Religious Affairs Office) which is located in almost all sub-districts in Indonesia. In accordance with PMA (Minister of Religion Regulation) Number 39 of 2012 concerning the Organization and Administration of the Office of Religious Affairs, this Satker has 7 functions, one of which is the guidance service for sakinah (harmonies) families. The function of this service is of course related to the guarantee of family resilience. From the dynamics of the fact of the service, the function of these services simultaneously with the implementation of the Pre-Marriage Course can be a medium of information for prospective brides or couples who will help and support the values of national and state life. Not only that, the Pre-Marriage Course can also become the identity of each of the prospective bridal couples.

Currently, the Ministry of Religion is promoting religious moderation in order to maintain the values of national and state life. The Minister of Religion, Lukman Hakin Saifuddin, called priority religious moderation an important priority program. The Ministry of Religion is trying to make Indonesians aware that the relationship between religion and the state is mutual. This priority program can rely on the Subdistrict Religious Affairs Office (KUA) service function in terms of forming sakinah (harmonies) families and organizing premarital courses. However, if it is potential to be carried out, it is necessary to conduct research related to one of these things. One of the researches that can be carried out is the implementation of the Pre-Marriage Course, because of the nature of the implementation which tends to be carried out routinely and is related to the basis for the formation and awareness of the community regarding religious relations with the state, namely through the family.

Family can be interpreted as a small environment from the image of a country. If family formation can be said to be good for a country, then it can be strongly suspected that the state has the social capital to easily realize the direction of its development. So that many state institutions make the family a field of continuous study. Such as the Ministry of Religion with the family sakinah (harmonies) program, the Ministry of Social Affairs with the family of hope, and the Ministry of Health with the Healthy Indonesia program with a family approach. However, only the Ministry of Religion has a family preparation program through pairs of prospective brides.

The pre-marriage course is one of the Ministry of Religion's programs in creating sakinah (harmonies) families. Sakinah (harmonies) family is defined as a legal marriage, able to fulfill spiritual and material needs in harmony and balance, surrounded by an atmosphere of love between the internal family and the environment. The Pre-Marriage Course is an effort to create a sakinah (harmonies) family, through provision for the bride and groom before starting their life as a family. In fact, the Pre-Marriage Course could be the final reflection material for Catin before she is really sure that she will get married. Whether they (Catin) is the right match or not, this can be obtained through the Pre-Marriage Course. 
Despite how strategic pre-marriage courses are for the Ministry of Religion and important for brides-to-be, is it possible to cultivate an attitude of moderation in religion? This is the point of this article being written. Of course it will try to provide an understanding of the importance of pre-marriage courses in preparing families in Indonesia.

\section{Pre Marriage Course}

In the Regulation of the Director General of Islamic Community Guidance Number DJ.II / 542/2013 concerning Guidelines for the Implementation of Pre-Marriage Courses (KPN ), it is stated in article 1 that this activity is defined as providing knowledge, understanding, skills, and raising awareness to adolescents of marriage age about life household and family. In this definition of Pre-Marriage Course, it is assumed that teenagers at the age of marriage or in this case the bride and groom do not have an understanding of domestic life.

Of course they can get information about household life from any source, for example from parents, friends, social media, and so on. However, the information they obtained was not complete. So it is possible that they only get information from one aspect only, for example about the rights of husbands and wives or others. This is where the function of the Pre-Marriage Course is given to the bride and groom.

Pre-Marriage Course can provide a complete understanding of married life. The information that will be obtained from the Pre-Marriage Course can be said to be very complete, starting from the foundation of state law and religion in the household, marriage procedures, introducing family functions, and handling domestic conflicts. More details on the material that will be obtained by the bride and groom in the Pre-Marriage Course are listed below:

1. The basic group

a. Ministry of Religion Policy on Development of Sakinah (harmonies) Families

b. Policy of the Directorate General of Islamic Community Guidance on Implementation of Pre-Marriage Courses

c. Legislations concerning marriage and family formation

d. The law of hypocrisy

e. Marriage procedure

2. The core group

a. Implementation of family functions

b. Caring for love in the family

c. Conflict management in the family

d. Psychology of marriage and family

3. Support group
a. Andragogical approach
b. Preparation of SAP (Learning Program Unit) and micro teaching
c. Pre test and post test
d. Assignment / action plan

\section{Religious Moderation}

Moderation in the Big Indonesian Dictionary means reducing violence, avoiding extremes. Meanwhile, in Arabic the word moderation is called al-wasathiyah which means 
justice, which is in the middle. This means that the word moderation can be interpreted in language as balance. In the Qur'an, the meaning of moderation is very much implied.

The meaning of moderation in the holy book of Al-Quran in Surah Al-Rahman verses 7-9, namely:

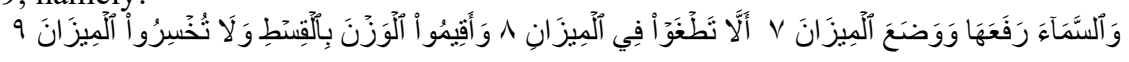

Meaning: 7). And Allah has lifted the heavens and He put a balance (justice). 8). So that you don't cross the line. 9). And uphold the balance fairly and do not reduce the balance.

Justice becomes the essence of the meaning of the direction of human life so that it does not live excessively. In that verse, the way of life does not transgress or exaggerate is to instill the principle of justice. This is one of the essences of how to have a moderate attitude. The principle of justice without the development of openness will be incomplete. In Surat AlHujurat verse 13 it is stated that:

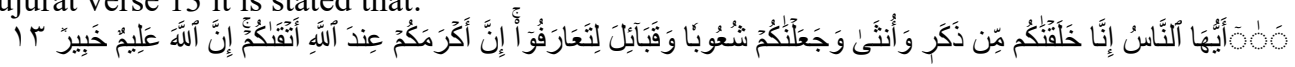

Meaning: (13) O people, verily We created you from a man and a woman and made you nations and tribes so that you would know each other. Indeed, the most noble among you with Allah is the most devout among you. Allah is All-Knowing, All-Knowing.

Verse 13 of the letter Al-Hujurat above reminds humans to be aware of the diversity that Allah created on this earth. If Allah wanted to create only one, then that could happen. However, Allah created all living things in this world in pairs and varieties. Human beings are asked to be aware of this so that they know each other. This command to get to know each other can be carried out with an open attitude towards the environment.

These two things are what the author underlines as the concept used regarding religious moderation in the Koran. Although there are other surahs and verses, the author views with an open attitude and principles of justice, the meaning of moderation in any case, including religion will be created. So, with the basis of how to respond to something, it will be easy to adjust to any change.

\section{Kurt Lewin's Change Program}

The context of this paper is about how pre-marriage courses can be a medium for prospective brides to accept change. The thing that they will naturally face as a change is the context of living together as a husband and wife. In this case, the author uses Kurt Lewin's theory of change. In his theory of change, Lewin offers a 3-step model towards fundamental change (Burnes, 2004). This can be seen in the following scheme: 


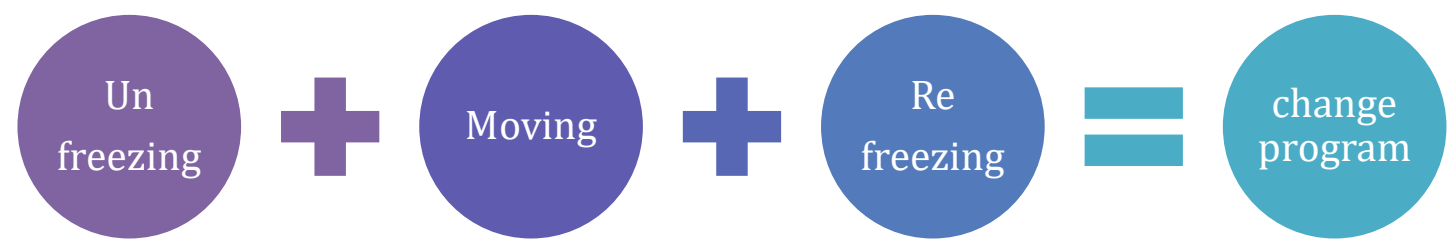

First, unfreezing can mean not being frozen. Lewin argues that basically, the desire to change behavior or habits begins with destabilizing old behavior or habits first. The first thing that needs to be done is to recognize the changes that will be faced. Then three things need to be done to be able to unfreezing, namely, agreeing on the need for change, accepting the anxiety that is being faced before making changes, and creating psychological comfort. This pattern can be seen in the following scheme:

\section{disconfirmation \\ of validity the status quo}

When this process can be passed, change by adopting the right behavior will be possible. If the context is a married couple, then each partner will apply the proper behavior of a husband and wife.

Second, moving can be defined as "displacement". This achievement is not as easy as it means. This stage requires a separate motivation. In each individual has a number of peculiarities in creating motivation. What needs to be done is identification and evaluation. 
Motivation here can be interpreted as reinforcing the desire to make a shift from old behavior patterns to new ones. This displacement step can be seen in the following scheme:

\section{identifikasi}

Third, refreezing can be interpreted as "re-freezing". This is the final step in the model change program stage. At this stage, the stabilization of the change in behavior is measured by the absence of old behavior. This stage will not be fully successful without other changes around it, such as culture, norms, policies and training. In the context of a husband and wife pair will carry out this stage if the new behavior is declared comfortable.

\section{Research methods}

This paper is based on the results of research conducted in Purwakarta, Indramayu, and Banjar Regencies regarding Subdistrict Religious Affairs Office (KUA) services in providing pre-marriage courses in prior to April 2015. The research was conducted using a qualitative approach. Data were collected using interviews, observations, and simple trials.

This paper is focused on the Subdistrict Religious Affairs Office (KUA) which organizes Pre-Marriage Courses in groups, namely the Subdistrict Religious Affairs Office (KUA) of Purwakarta, Indramayu, Widasari, and Purwaharja Subdistricts. What is observed and used as a source of data from this paper is that the bride and groom took part in the premarriage course at the Subdistrict Religious Affairs Office (KUA) in prior to April 2015. During the Pre-Marriage Course which was observed in groups, on average there were 21 to 30 pairs of prospective brides taking the course pre-marriage. Some of them bring their prospective bride and groom, some don't, and some are accompanied by relatives or friends. But on average $75 \%$, they brought their partner.

At first, when the course was conducted, the initial researcher observed the prospective brides who were not all present to listen to material from the Subdistrict Religious 
Affairs Office (KUA) apparatus. Broadly speaking, the material presented by the Subdistrict Religious Affairs Office (KUA) includes material written in Perdirjen Number DJ.II / 542/2013, namely Ministry of Religion policies, policies of the Directorate General of Islamic Community Guidance on pre-marriage courses, laws and regulations on marriage and family fostering, law of munakah, and marriage procedures. These materials are presented briefly and clearly. Then in the next material the implementation of family functions, caring for love, conflict management, and marriage psychology is presented. Similar to the delivery of material by the first speaker, the second speaker also delivers briefly and clearly.

Furthermore, the researcher asked the participants and the presenters time to conduct a trial by providing interactive material to participants in the pre-marriage course. Researchers provide material on the introduction of self-concepts, elaborate on the function of husband and wife by mapping the potential of each bride and groom, and interviewing some of the prospective brides.

\section{Discussion}

The results of what researchers have done to prospective brides in pre-marriage courses at several Subdistrict Religious Affairs Office (KUA) districts in prior to April 2015, namely:

1. Introduction of the self-concept of each bride and groom

In the introduction of this self-concept, there are couples who already know each other, some don't know each other, and some who half know each other.

\section{The function of husband and wife}

In this introduction to the functions of husband and wife, researchers stimulate their potential attitudes in the family. This is done to determine the initial knowledge from researchers about their attitudes when taking the role of husband and wife.

Then the researcher offers a moderate attitude in the household. In this case the researcher refers to the letter Ar-Rahman verses 7-9, which in essence is important to display a moderate attitude in order to achieve justice.

3. Interview

Then, the researchers tried to capture prospective bridal couples who were purposively interviewed. The choice of interviewees was based on the enthusiasm of the bride and groom and those who were not fully familiar with their partner's self-concept.

From the results of the researcher's study of the implementation of the sub-district Subdistrict Religious Affairs Office (KUA) service in Pre-Marriage Course, an understanding was obtained about how to change the understanding that was raised in the commitment to being husband and wife. Of course, the trends in each prospective bride and groom in each region are not necessarily the same. But at least, the understanding of researchers will provide an overview of the concept of change that can be contained in the Pre-Marriage Course.

Broadly speaking, the results of the researchers' understanding can be seen in table 1 below. The following table shows the stages of Kurt Lewin's change model, starting from 
unfreezing, moving, and refreezing. The unfreezing begins with data collection about the old habits of the prospective bride and groom. Then they agreed to make changes, because they had anxiety about the appearance of disharmony in their relationship as husband and wife. So that in the end raises their supposition of psychological comfort. In creating this condition of psychological comfort they create motivation in the household. And finally, they agreed that they would bring up new habits in the household. Of course, these changes need to be constantly evaluated, such as by trying to study and understand the state of their respective environments.

Table 1.

Program to Change the Pre-Marriage Course subdistrict religious affairs office (KUA) target districts

\begin{tabular}{|c|c|c|c|c|c|}
\hline \multicolumn{3}{|c|}{ Unfreezing } & \multirow{2}{*}{$\frac{\text { Moving }}{\text { Motivation }}$} & \multicolumn{2}{|c|}{ Refreezing } \\
\hline Old habits & $\begin{array}{l}\text { Agree to } \\
\text { change and } \\
\text { accept } \\
\text { anxiety }\end{array}$ & $\begin{array}{l}\text { Psychological } \\
\text { comfort }\end{array}$ & & $\begin{array}{l}\text { New } \\
\text { habits }\end{array}$ & $\begin{array}{c}\text { Enviromental } \\
\text { Support }\end{array}$ \\
\hline $\begin{array}{l}\text { Get together } \\
\text { with friends }\end{array}$ & $\begin{array}{l}\text { Anxious } \\
\text { about } \\
\text { disharmony } \\
\text { and a desire } \\
\text { for change }\end{array}$ & $\begin{array}{l}\text { Arrange a time } \\
\text { to meet friends }\end{array}$ & $\begin{array}{l}\text { Life long } \\
\text { partner, } \\
\text { advanced } \\
\text { and rich } \\
\text { together, }\end{array}$ & $\begin{array}{l}\text { Inform } \\
\text { each other } \\
\text { to the } \\
\text { partner }\end{array}$ & $\begin{array}{l}\text { The state of } \\
\text { the family, the } \\
\text { state of the } \\
\text { job, the state } \\
\text { of the friends }\end{array}$ \\
\hline Hedonistic & & Not hedonistic & $\begin{array}{l}\text { realizing } \\
\text { dreams } \\
\text { together, } \\
\text { harmonious } \\
\text { relationship }\end{array}$ & $\begin{array}{l}\text { Divide } \\
\text { roles in } \\
\text { managing } \\
\text { finances }\end{array}$ & \\
\hline Individualist & & $\begin{array}{l}\text { Accept } \\
\text { partner's } \\
\text { family } \\
\text { presence }\end{array}$ & & $\begin{array}{l}\text { Visiting } \\
\text { partner's } \\
\text { family }\end{array}$ & \\
\hline Tempramental & & $\begin{array}{l}\text { Be calm in } \\
\text { dealing with } \\
\text { problems }\end{array}$ & & $\begin{array}{l}\text { Instill } \\
\text { positive } \\
\text { and calm } \\
\text { thoughts } \\
\text { in the face } \\
\text { of } \\
\text { problems }\end{array}$ & \\
\hline
\end{tabular}




\begin{tabular}{|l|l|l|l|l|}
\hline $\begin{array}{l}\text { Easily attracted } \\
\text { to other partners }\end{array}$ & $\begin{array}{l}\text { Be loyal to } \\
\text { your partner }\end{array}$ & $\begin{array}{l}\text { Be loyal } \\
\text { to your } \\
\text { partner }\end{array}$ \\
\cline { 1 - 1 } Not religious & & Religious & $\begin{array}{l}\text { Diligently } \\
\text { worship } \\
\text { together }\end{array}$ \\
\cline { 1 - 2 }
\end{tabular}

* Note: Researchers try to classify from a number of potential notes about old habits and the emergence of new habits.

In table 1 above, the old habits of the 21 Pre-Marriage Course participants at the Subdistrict Religious Affairs Office (KUA) are classified by researchers, namely, they have old habits that tend to be obstacles in later family life, such as frequent gathering with friends regardless of time, buying luxury items excessively, does not like to share stories with people who are not of the same view (more trust in friends), often displays anger in facing problems, likes to have relationships with many partners, and rarely performs religious activities (prayer and recitation).

Because of their old habits, there is anxiety about the relationship that is not harmonious and does not last long (let's say, the threat of divorce). They have an agreement to build a close relationship with each other. This is an agreement to make changes that arise from their respective statements. Like the appearance of the word, "don't want, don't want to, otherwise it won't happen".

Then, they each agreed to change their old habits, such as adjusting the time when they wanted to meet friends, not spending money, accepting their partner's family, being calm when facing problems, being loyal to their partner, and being religious. This agreement is strengthened by their motivation to live together harmoniously, faithfully, and with the desire to realize dreams together.

They hope that they will generate new habits such as, informing each other when they want to travel, dividing their roles in managing finances, visiting their partner's family, instilling positive thoughts when facing problems, being loyal to their partner, and being diligent in worshiping together. This new habit will be influenced by the environment of each partner, such as family conditions, work, and friends. So that an adjustment is needed to the situation.

Researchers obtained an understanding of the importance of Pre-Marriage Course for the prospective bride and groom through interviews with several participants. This PreMarriage Course is seen by one of the participants as being able to foster mutual respect and respect between partners. As revealed by $\mathrm{ZN}$ during an interview:

"This pre-marriage course can generate mutual respect and openness between husband and wife partners"

This statement from one of the couples or Pre-Marriage Course participants indicates that it is necessary to create mutual respect and openness when married. This can also be said to create a moderate attitude in the family environment, it is realized that the prospective bride 
and groom need to exist. This moderate attitude begins in household life, then is accustomed to their social environment.

Old habits that they realize will interfere with their family relationships need to be identified and then replaced with new habits. This is represented by a statement by one of the IN participants;

"The habit of wasting salary money when you are still alone needs to be abandoned when you are married. If what I know, my future husband liked to hang out with his friends until he lost track of time, this should also be eliminated. Others, such as rarely praying and lazy to stay in touch, also need to be eliminated"

This is a habit that can exist in other couples. Another habit that is no less important, is even one of the causes of spouse divorce, namely, "cheating". This habit begins with an attraction to another partner before committing to a household relationship. According to one of the domestic participants, this habit also needs to be eliminated once they are married;

"The habit of my boyfriend or my future husband used to love chatting with other female friends. He has a lot of friends on Facebook who I often see to establish close relationships, from his inbox I like to see the messages"

One of the additional information that the researchers obtained was related to the trigger for the breakdown of the husband and wife relationship in Purwakarta from one of the religious leaders of the Subdistrict Religious Affairs Office (KUA) Purwakarta, namely, the influence of social media which is often misunderstood by couples, then disputes arise. This headman (KUA's Worker) with the initials TF said that:

"Most of what I pay attention to and from most who consult with me, they (husband and wife) complain about their partner's friendship on social media.

There are many triggers for harmonious husband and wife relationships. One of them is understanding the habits of each partner before marriage. This can be open to understanding, through Pre-Marriage Course"

Even though most of the Pre-Marriage Course participants did not know the program that was given before they got married, they considered it important that the Pre-Marriage Course program be held even though there was a lack of availability of facilities and infrastructure owned by the Subdistrict Religious Affairs Office (KUA). This can be seen in the statements of some participants regarding the implementation of Pre-Marriage Course:

"Actually, this course is very important for us to know. At first I didn't know the name Suscatin or courses. We know from the invitation given by the Subdistrict Religious Affairs Office (KUA). Then we were interested in knowing it and it turned out to be important to us. But why is it called a course and it is short done? It should have been from the start that the length of time it would be held in accordance with the material presented. We'll accept that. Or just replace it with the term seminar, if you want it to be held in a short time. Through this PREMARRIAGE COURSE we can know how to be a good husband and wife according to religion and country. Then we know how to build a relationship to become a sakinah (harmonies) family. And we are also told how to pray when "relating" husband and wife. This Pre- 
Marriage Course is important to hold. It's just that, the packaging of the material and the speakers must be people who are capable (competent or appropriate) in their field. The material about how to "relate" a husband and wife, the speaker is from a religious figure, it should be someone in charge of health (let's call it a gynecologist). Apart from that, we also hope that the support for facilities and infrastructure during the implementation of the PreMarriage Course needs to be improved".

The results of the researcher's study of the implementation of Pre-Marriage Course in the sub-district Subdistrict Religious Affairs Office (KUA) provide an understanding that the program is very effective in introducing and making the prospective bride and groom aware of a good family life. The creation of a physically and psychologically healthy family is decisive for the development of the Indonesian state. Mainly, planting a moderate attitude in the household can be made aware of from an early age for the prospective bride and groom. This attitude will determine the creation of a harmonious relationship between partners.

\section{Conclusion}

The researchers concluded that, religious moderation can be started from the time of ordering the family through marriage. Marriage is a religious guide. The formation of a sakinah (harmonies) or harmonious family is a great hope for couples and is very popular with any religion, including Islam. The pre-marriage course is a medium that can be used as a means of psychological change for the bride and groom. Psychological changes for the bride and groom through pre-marriage courses can use Kurt Lewin's concept of change. This concept of change directs the situation to be able to open up and accept the future of the bride and groom. Openness of attitude and willingness to accept changes from moderation, and can be a capital to be developed in any direction, including moderation in religion. This is because, the essence of moderation can be implemented as part of building a happy or harmonious family.

\section{Suggestion}

Researchers suggest that:

1. There needs to be more program changes to the implementation of Pre-Marriage Course in other Subdistrict Religious Affairs Office (KUA), so that it can better map and teach the formula for changing the prospective bride and groom.

2. Ministry of Religion needs to facilitate the implementation of the Pre-Marriage Course at each Subdistrict Religious Affairs Office (KUA) in the country, such as the addition of facilities and infrastructure, readiness of materials and presenters, and socialization of the implementation of the importance of the Pre-Marriage Course for prospective brides.

\section{References}

Bogdan, Steven J dan Taylor, 1992, Metodologi Penelitian Subdistrict Religious Affairs Office (KUA)litatif, Suatu Pendekatan Fenomenologis Terhadap Ilmu-Ilmu Sosial, (Terj) Arif Furkhan: Surabaya: Usaha Nasional 
BPS, 2013, Proyeksi Penduduk Indonesia 2010-2035, Jakarta: BPS.

Burnes, Bernard, 2004, Kurt Lewin and The Planned Approach to Change: A Re-appraisal, Jurnal of Management Studies 41: 6 September 2004 0022-2380, Black Well Publishing: USA.

Cammack, Marc, Lawrence A. Young, Tim B. Heaton, 1997, An Emperical Assesment of Divorce Law in Indonesia. Studia Islamika, Indonesian Journal for Islamic Studies. Vol. 4, No.4

Denzin, Norman K dan Yvonna S. Lincoln (Eds), 1994, Handbook of Qualitative Research, California: SAGE Publications.

Denzin, Norman, K., Yvonna, S., Lincoln, 1994, Handbook of Qualitative Research. California: SAGE Publications

Dirjen Bimas Islam, Direktorat Urusan Agama Islam dan Pembinaan Syariah, 2011, Pedoman Penyelenggaraan Kursus Pra Nikah.

Dirjen Bimas Islam, Direktorat Urusan Agama Islam dan Pembinaan Syariah, 2013, Pedoman Penyelenggaraan Kursus Pra Nikah.

Faiz, Aminudin, 2008, Bimbingan Seksualitas Pranikah dalam Perspektif Islam, Skripsi, UIN Sunan Kalijaga: Yogyakarta.

Horton, Paul B., Chester L, Hunt, 1999, Sosiologi (alih bhs) Aminuddin Ram, Tita Sobari Jakarta: Erlangga

Idris Ramulyo, Mohd, 2004, Hukum Perkawinan Islam; Suatu analisis dari Undang-Undang No.1 Tahun 1974 dan Kompilasi Hukum Islam. Jakarta: PT Bumi Aksara

Ismail, 2015, Pelayanan Bimbingan Pra Nikah di KUA (Studi Kasus di KUA Kecamatan Indramayu dan Kecamatan Widasari Kabupaten Indramayu, makalah seminar hasil penelitian, Balai Litbang Agama Jakarta.

Jones, Gavin W., 1994, Marriage and Divorce in Islamic South-East Asia, Oxford University Press.

Mazmanian, Daniel A and Paul A. Sabatier, 1983, Implementation and Public Policy, Illinois. Scott: Foresman and Company.

McNicoll, Geoffrey and Masri Singarimbun, 1983, Fertility Decline in Indonesia: Analysis and Interpretation. Washington, D.C: National Academies Press.

Mulyana, Dedy, 2002, Metode Penelitian Subdistrict Religious Affairs Office (KUA)litatif, Paradigma Baru Ilmu Komunikasi dan Ilmu Sosial Lainnya, Bandung: Remaja Rosdakraya.

Perdirjen Bimas Islam Nomor DJ.II/542/2013. Pedoman Penyelenggaraan Kursus Pra Nikah. Bimas Islam: Kementerian Agama.

Rabitha, Daniel, 2015, Penyelenggaraan Kursus Pra Nikah di Kabupaten Purwakarta: Kasus SUBDISTRICT RELIGIOUS AFFAIRS OFFICE (KUA) Purwakarta, Cibatu, dan Babakan Cikao, Jurnal Penelitian Keagamaan dan Kemasyarakatan (Penamas), Volume 28, No.3, Oktober-Desember 2015.

Ritonga, Iskandar, 2005, Hak-Hak Wanita Dalam Putusan Peradilan Agama, Jakarta: Ditjen Bimas Islam dan Penyelenggaraan Haji Departemen Agama

Santoso, Amir, 1988, Analisis Kebijaksanaan Publik, Jurnal Ilmu Politik, No. 3. PT.Gramedia. Jakarta

Sarayreh, Hussein, Bashar., Khudair, Hassan., Barakat, Alabed, Eyad, 2013, Comparative Study: The Kurt Lewin of Change Management, International Journal of Computer and Information Technology; volume 02, 4 Juli 2013. www.ijcit.com

Shcein, H., Edgar, 1996, Kurt Lewin's Change Theory in the Field and in the Classroom: Notes Toward a Model Managed Learning, Reflection volume 1 nomor 1

Subdistrict Religious Affairs Office (KUA) Kec. Mranggen (Studi Analisis Bimbingan Konseling Perkawinan), Skripsi., IAIN Walisongo Semarang.

Subhan, Zaitunah, 2004, Membina Keluarga Sakinah (harmonies), Yogyakarta: Pustaka Pesantren

Syarifuddin, Amir, 2007, Hukum Perkawinan Islam di Indonesia: Antara Fiqh Munakahat dan UndangUndang Perkawinan. Jakarta: Kencana

Trochim, William M, 2006, The Research Methods Knowledge Base, 2nd Edition, Internet WWW page, at URL: <http://www.socialresearchmethods.net/kb/> (versi terakhir hingga 20 Oktober 2006).

Undang-Undang Nomor 25 Tahun 2009 tentang Pelayanan Publik.

Wahab, Solichin Abdul, 1997, Analisis Kebijaksanaan dari Formulasi ke Implementasi Kebijaksanaan Negara, Bumi Aksara: Jakarta 
Yin, Robert K, 2003, Case Study: Research Design and Methods, Edisi ke-3, Thousand Oak, Calif.: Sage Publications.

Zakaria, Abi.tt., Fathul Wahab bi Syarhi Minhaji al-Thulab, Semarang: Nur Asia

Zulaekha, Oktaviani, 2013, Bimbingan Konseling Pra Nikah bagi Calon Pengantin di BP4. 